\title{
The Good, the Bland and the Ugly-Further Analysis of Why the Yorubas Took the Pax Britannica Chloroform
}

\section{Ayoade $\mathrm{S}^{*}$}

Independent Researcher, Alumnus, College of Medicine University of Ibadan, Nigeria

*Corresponding author: Seun Ayoade, BSc (Hons) Physiology, Independent Researcher, Alumnus, College of Medicine University of Ibadan, Oyo State, Nigeria, Tel: +2348060221764; Email: SeunAyoade@protonmail.com

\section{Opinion}

Volume 5 Issue 2

Received Date: September 13, 2021

Published Date: September 23, 2021

DOI: $10.23880 / \mathrm{mhrij}-16000150$

"A great civilization is not conquered from without until it has destroyed itself within." -Will Durant

\section{Opinion}

Whereas it has been theorized that the Yoruba were colonized by the British because of their illiteracy [1] that does not give $100 \%$ of the picture. Shouldn't their "native intelligence" and common sense have told the Yoruba pagans that in this world nothing goes for anything and that there had to be a catch for the British so readily playing peacemaker? And why didn't the Yorubas ask for a stipulation of time limit for British colonial occupation? Apart from their illiteracy which the Yoruba intelligentsia capitalized upon to deceive the Yoruba illiterates two other factors explain why the 19th century Yoruba pagans took the pax Britannica chloroform so readily. The first factor was because they were war weary. The second factor was because of their flawed perception of Europeans. We must remember that the Yoruba masses of the 19th century knew next to nothing about Europeans in general and the British in particular and what they did know were mostly half-truths. Apart from the Egba city of Abeokuta which had a sizeable number of Europeans (and which embraced Christianity early) most Yoruba had hardly ever set their eyes on more than half a dozen white people their entire lives. Most had never gotten close enough to Europeans to speak to them, not to talk of give one a handshake or sharing a meal. And those, such as the pagan rulers and military commanders who had actually spoken [through interpreters] to white people at close quarters had a flawed perception of whites and the western world. They saw Europeans in three phases, stages and categories-The Good, The Bland and the Ugly.

The Good-the first white people the Yoruba encountered were the white missionaries and explorers. They brought free gifts to the people and taught the natives how to read and write and provided medicine and surgery free of charge. They were warm, friendly, and generous to a fault and propagated a religion which proclaimed that their salvation and ticket to heaven had been freely paid for 1800 plus years ago. It is no wonder the Yoruba masses associated freebies with white people and could believe the British had no ulterior motives in "protecting" them with colonial troops. The most famous of this class were Richard Lander, Clapperton, William $\mathrm{H}$ Clarke, R.H. Stone, Bowen, The Hinderers etcetera. The Bland-these were the white traders and merchants who sold the Yoruba guns, gunpowder, intoxicating liquors, telescopes, field glasses, rockets, rifles and tobacco. They didn't preach the Gospel or give the Yoruba free gifts. They were somewhat cold and business like, rarely left the coast and collected cash crops [mostly palm oil and cotton] as payment. They did not interfere with or try to enlighten the Yoruba like the missionaries and explorers did.

The Ugly-finally the Yoruba were brought into contact with the colonizers. They took Lagos first, then the hinterland in 1886. All illusions of a Santa Claus like European were eventually shattered. But we must remember that in 1886 the Yoruba were very war weary and had been fighting intermittent wars for over two decades. They were ready for peace at almost any cost. The desperation of war obscures rational thinking, diminishes judgment and lowers moral standards. The Goths, when besieged by atilla the Hun sold their children to the Romans in exchange for dog meat! [2]. At the close of World War Two many otherwise sensible German and Japanese girls sold their bodies very cheaply 


\section{Mental Health \& Human Resilience International Journal}

to American soldiers. So the educated Yoruba Christian Intelligentsia callously sold their illiterate brothers and sisters to the British in a misplaced zeal to spread Christianity to them, but the war weariness and flawed perception of European/ British intentions by the Yoruba pagan masses also played a role. But what would have been the fate of The Yoruba if they were not involved in internecine wars in that fateful year of 1886? A total escape from colonization? Colonization by the French? [France was in touch with some Yoruba monarchs before British colonization] Semicolonization? An alliance with Portugal? Would the Yorubas have gone Lusophone? [The Yoruba city state of Lagos was in weak alliance with Portugal before being conquered by the British in 1851.] Or would they have been briefly colonized, attaining independence in the 1920 s or earlier?.

\section{References}

1. Ayoade S (2021) A Tale of Two Empires: A Forensic Analysis of How and Why the Ethiopians Escaped Colonization but the Yorubas Did Not. Anthropol Ethnol Open Acc J 4(1): 000141.

2. Thomas SB (1994) Barbarians within the Gates of Rome: A Study of Roman Military Policy and the Barbarians, Ca. 375-425 A.D. Bloomington and Indianapolis: Indiana University Press, pp: 448. 